\title{
Thermoperiodicity in Shoot Elongation of Purple Nutsedge
}

\author{
Wen-Hao Sun ${ }^{1}$ and Roy K. Nishimoto ${ }^{2}$ \\ Department of Horticulture, University of Hawaii, Honolulu, HI 96822-2279
}

AdDITIONAL INDEX WORDs. alternating temperature, fluctuating temperature, budbreak, sprouting, Cyperus rotundus

\begin{abstract}
The effect of single and daily alternating temperature cycles on elongation of emerged buds of purple nutsedge (Cyperus rotundus L.) was characterized to determine whether shoot elongation responded to alternating temperature as a thermoperiodic function. Glasshouse-grown tubers with emerged buds of 2 to $5 \mathrm{~mm}$ in length were used in experiments. Shoot extension increased at $35{ }^{\circ} \mathrm{C}$ after 7 days, but no significant shoot extension occurred at all other constant temperatures of $20,25,30,40$, and $45{ }^{\circ} \mathrm{C}$. However, 2- to 8-fold increases in shoot extension occurred at alternating temperatures of $25 / 15,30 / 20,35 / 25,40 / 30,41 / 35,42 / 38$, and $45 / 35{ }^{\circ} \mathrm{C}(12 / 12$ hours $)$ as compared to the respective mean constant temperatures. Daily temperature differences of 2 and $4{ }^{\circ} \mathrm{C}$ did not stimulate shoot elongation, while temperature differences of 8 and $12{ }^{\circ} \mathrm{C}$ caused an 8-fold shoot stimulation when compared to the $24{ }^{\circ} \mathrm{C}$ constant temperature. Shoot elongation increased with increasing numbers of alternating temperature cycles. The optimal duration of the lower and upper temperature phases differed depending on temperature regimes; at $40 / 30{ }^{\circ} \mathrm{C}$, maximal elongation occurred with daily exposures of $40{ }^{\circ} \mathrm{C}$ for 1 to 3 hours and $30{ }^{\circ} \mathrm{C}$ for 23 to 21 hours respectively, while at 30/20 ${ }^{\circ} \mathrm{C}$, maximal elongation occurred with daily exposures of $30^{\circ} \mathrm{C}$ for 15 hours and $20^{\circ} \mathrm{C}$ for 9 hours. These results suggest that elongation of purple nutsedge tuber buds responds to alternating temperature as a thermoperiodic function.
\end{abstract}

Sprouting of single tubers of purple nutsedge is thermally regulated (Holt and Orcutt, 1996; Miles 1991; Miles et al., 1996; Tripathi 1967; Ueki 1969). Miles et al. (1996) studied the effect of alternating temperatures on purple nutsedge tuber sprouting and showed that all tubers sprouted under alternating temperatures (35/ $25{ }^{\circ} \mathrm{C}, 12 / 12 \mathrm{~h}$ ), while only $66 \%$ sprouted within 4 weeks at the constant mean temperature $\left(30{ }^{\circ} \mathrm{C}\right)$. They defined sprouting as budbreak and shoot elongation to $\geq 10 \mathrm{~mm}$.

Purple nutsedge tuber sprouting probably involves two steps: budbreak and elongation of the emerged bud (Nishimoto et al., 1995). Budbreak occurred within 2 weeks for $\approx 75 \%$ of the tubers at constant $20^{\circ} \mathrm{C}$, or at relatively constant temperatures of $\approx 23^{\circ} \mathrm{C}$ in the laboratory, but only $\approx 10 \%$ of the emerged buds elongated $>10 \mathrm{~mm}$ (Nishimoto et al., 1995). Nearly all of the remaining dormant tubers were induced to the budbreak stage by a single 30min $35^{\circ} \mathrm{C}$ pulse (Sun and Nishimoto, 1997). Thus, the budbreak process occurs readily and can be triggered by high temperature. However, there is no information on thermal regulation of bud elongation of purple nutsedge. This research focused on the response of the elongation of the emerged bud to alternating temperatures and whether the response is thermoperiodic.

Thermoperiodicity or thermoperiodism refer to a physiological response of an organism to the alternation of high and low temperatures. The term thermoperiodicity in plants was coined by Went (1944). Went (1944) and other researchers (Dale, 1964; Friend and Helson, 1976; Wellensiek, 1957) indicated that the thermoperiodic effect could stimulate plant growth and development; their definition assumed that light and associated growth was important during part of the daily cycle. The thermoperiodicity concept provides a framework for characterizing the elongation response of purple nutsedge buds.

Received for publication 29 June 1998. Accepted for publication 5 Nov. 1998. This paper represents a portion of a PhD dissertation by W.H.S. Hawaii Institute of Tropical Agriculture and Human Resources journal series no. 4380. The cost of publishing this paper was defrayed in part by the payment of page charges. Under postal regulations, this paper therefore must be hereby marked advertisement solely to indicate this fact.

${ }^{1}$ Former graduate research assistant. Currently postdoctoral research associate, Department of Plant Molecular Physiology, University of Hawaii.

${ }^{2}$ Professor, to whom reprint requests should be addressed.
Thermoperiodicity is the plant response to alternating temperature rather than to different absolute temperatures. It is difficult to separate effects of alternating temperature from effects of the different temperatures themselves. The use of constant upper, lower (Went, 1944), or mean temperature of the alternation cycle (Haroon et al., 1972; Lionakis and Schwabe, 1984; Wellensiek, 1957) as a reference temperature is not sufficient to demonstrate thermoperiodicity because the growth response to constant temperature is not linear over a wide temperature range. The choice of suboptimal or supraoptimal temperatures for experiments can cause inconsistent effects over a wide temperature range (Friend and Helson, 1976). Thus, Dale (1964) and Friend and Helson (1976) tested for thermoperiodicity by assessing growth (dry weight, stem elongation, etc.) at the constant temperature where optimal growth occurred and compared that with growth at the alternating temperature regime with the same diurnal mean.

Thermoperiodism is not a phenomenon common to all species. Using Dale's definition of thermoperiodism, no evidence was found for a thermoperiodic response in dry weight of bean (Phaseolus vulgaris L.), cucumber (Cucumis sativus L.), maize (Zea mays L.), oat (Avena sativa L.), pea (Pisum sativum L.), tomato (Lycopersicon esculentum Mill) and wheat (Triticum aestivum L.) (Dale, 1964; Friend and Helson, 1976). A number of studies showed that growth of sugar cane (Saccharum officinarum L. hybrid 'Pintar') (Glasziou et al., 1965), sugar beet (Beta vulgaris L.) (Ulrich, 1952), tobacco (Nicotiana tabaccum L.) (Haroon et al., 1972), soybean (Glycine max (L.) Merr) (Warrington et al., 1977), and cotton (Gossypium hirsutum L.) (Rajan and Blackman, 1975) under diurnally alternating temperature conditions was not greater than under constant temperature conditions with the same diurnal mean; these results indicate that there could be no thermoperiodicity in those plants when using growth parameters. However, the stimulation of germination by alternating temperature that occurs in numerous seeds (Benech Arnold et al., 1988; Harrington, 1923; Morinaga, 1926; Nishimoto and McCarty, 1997; Thompson et al., 1977; Totterdell and Roberts, 1980) would be expected to be classified as thermoperiodic if the proper alternating and constant temperature comparisons were made.

These experiments were designed to determine if shoot elongation responded to alternating temperature as a thermoperiodic 
function, using Dale's (1964) criterion to test for thermoperiodicity. The shoot elongation response to attributes of the alternating temperature function such as the magnitude of the daily alternating temperature, the number of alternating cycles, and variations in the duration of lower and upper temperature was characterized.

\section{Materials and Methods}

Tuber Selection AND Growth Conditions. Purple nutsedge tubers were obtained from glasshouse-grown plants and incubated at $20{ }^{\circ} \mathrm{C}$ for at least one week as described by Sun and Nishimoto (1997). After further incubation at prescribed temperature conditions for these experiments, tubers that had at least one sprout 2 to $5 \mathrm{~mm}$ in length were subjected to temperature treatments. Sprouted tubers were incubated on two layers of filter paper moistened with $3.5 \mathrm{ml}$ deionized water in a $100 \times 15 \mathrm{~mm}$ petri dish enclosed in a polyethylene bag to conserve moisture. The relative humidity in the incubator was maintained at $60 \%$ to $70 \%$.

Temperature Treatments. Programmable incubators $( \pm 1.0$ ${ }^{\circ} \mathrm{C}$ ) were used for the daily alternating temperature regimes with equal duration $(12 \mathrm{~h}$ ) of upper and lower temperature. The shorter periods of alternating temperatures were provided by transferring tubers between incubators at designated temperatures for the required time intervals. It took $\approx 30 \mathrm{~min}$ for the tuber's surface temperature to change from 20 to $35^{\circ} \mathrm{C}$ or vice versa, and this time was included in the reported heating times.

Thermoperiodic EFFECT. Tubers with budbreak were incubated at constant $25{ }^{\circ} \mathrm{C}$ for $7 \mathrm{~d}$ before use in this experiment. The optimal constant temperature for shoot elongation was determined by comparing shoot elongation under six constant temperatures ranging from 20 to $45^{\circ} \mathrm{C}$ at intervals of $5{ }^{\circ} \mathrm{C}$. The alternating temperature regimes of $25 / 15,30 / 20,35 / 25$, and $40 / 30{ }^{\circ} \mathrm{C}$ at $12 \mathrm{~h}$ for each temperature were compared to the constant temperature regimes to assess for thermoperiodicity of shoot elongation.

An experiment was also conducted to determine the elongation response at constant and mean alternating temperatures above the optimum of $35^{\circ} \mathrm{C}$. The treatments included constant temperatures of 38,40 , and $42^{\circ} \mathrm{C}$, and alternating temperature regimes of $41 / 35$ ${ }^{\circ} \mathrm{C}$; $42 / 38{ }^{\circ} \mathrm{C}$; $45 / 39{ }^{\circ} \mathrm{C}$; and $45 / 35{ }^{\circ} \mathrm{C}$, all at $12 \mathrm{~h}$ for each temperature. Tubers were held at constant temperatures of $25^{\circ} \mathrm{C}$ for $7 \mathrm{~d}$ before initiation of the treatments.

Magnitude OF DAILY ALTERNATING TEMPERATURES. Tubers with budbreak were incubated at constant $24{ }^{\circ} \mathrm{C}$ for $7 \mathrm{~d}$ before treatments of $24 / 24,25 / 23,26 / 22,28 / 20$, and $30 / 18{ }^{\circ} \mathrm{C}$ for another $7 \mathrm{~d}$; daily temperature differences were $0,2,4,8$, and $12{ }^{\circ} \mathrm{C}$, respectively. The duration of the high and low temperature phases was 12 $\mathrm{h}$ each.

NuMBER OF ALTERNATING TEMPERATURE CYClES. Tubers were incubated at constant $20^{\circ} \mathrm{C}$ for $7 \mathrm{~d}$ before treatments of one, three, five and seven daily alternating temperature cycles of $40 / 20{ }^{\circ} \mathrm{C}(1 /$ $23 \mathrm{~h}$ ). After the specified number of daily alternating cycles, tubers were maintained at constant $20{ }^{\circ} \mathrm{C}$. The effect of cumulative heat of each high temperature pulse on shoot elongation was assumed to be negligible due to the short period of high temperature.

DURATION OF UPPER AND LOWER TEMPERATURE PHASES. Tubers with budbreak were incubated at $25^{\circ} \mathrm{C}$ for $7 \mathrm{~d}$ before treatments. Two alternating temperature regimes $\left(30 / 20^{\circ} \mathrm{C}\right.$ and $\left.40 / 30{ }^{\circ} \mathrm{C}\right)$ with different exposure times at the upper and lower temperature regimes were imposed for $7 \mathrm{~d}$. The upper and lower phase temperatures were $0 / 24 \mathrm{~h}, 1 / 23 \mathrm{~h}, 3 / 21 \mathrm{~h}, 6 / 18 \mathrm{~h}, 9 / 15 \mathrm{~h}, 12 / 12 \mathrm{~h}, 15 / 9 \mathrm{~h}, 18 /$ $6 \mathrm{~h}, 21 / 3 \mathrm{~h}, 23 / 1 \mathrm{~h}$, and 24/0 h, respectively.

Shoot Length Measurements. The shoot length from the bud base to the tip of the scale leaf or primary leaf was measured after
$7 \mathrm{~d}$. If one tuber possessed several shoots, the longest shoot was reported. Miles et al (1996) recorded a tuber as sprouted if a shoot exceeded $10 \mathrm{~mm}$, and, to provide a basis for comparison, the number of shoots longer than $10 \mathrm{~mm}$ was also recorded.

STATISTICAL ANALYSIS. Each experiment was conducted as a completely randomized design, consisting of four replicate dishes per treatment with 10 tubers per dish. All experiments were conducted at least twice, but some repeat experiments had slightly different temperature regimes. Results between experiments were similar, and data from one of the experiments are shown. Data were subjected to analysis of variance (ANOVA) to determine sources of variation and provide the estimates for calculating the standard errors of means. The sprouting response to the number of daily alternating temperature cycles was analyzed by nonlinear regression. Duncan's multiple range test was used to determine whether treatments were significantly different.

\section{Results}

THERMOPERIODIC EFFECT. The optimal constant temperature for shoot elongation of purple nutsedge was $35^{\circ} \mathrm{C}$, where shoot length was $16 \mathrm{~mm}$ after $7 \mathrm{~d}$ incubation (Fig. 1). At constant temperature of $20,25,30,40$, and $45^{\circ} \mathrm{C}$, shoot length was only 1 to $6 \mathrm{~mm}$, and the means were not different from each other (Fig. 1). At $45^{\circ} \mathrm{C}$, no growth occurred and most shoots were necrotic.

Shoot elongation at all alternating temperature regimes was greater than at the respective constant temperature regimes (Fig. $1)$. The longest shoot length $(58 \mathrm{~mm})$ occurred at the alternating temperature regime of $35 / 25^{\circ} \mathrm{C}$, and was $>8$-fold greater than at the $30{ }^{\circ} \mathrm{C}$ constant temperature (Fig. 1). Shoot elongation was $>2$-fold greater at the alternating temperature regime of $40 / 30{ }^{\circ} \mathrm{C}(12 / 12 \mathrm{~h})$, than at the $35^{\circ} \mathrm{C}$ optimal constant temperature (Fig. 1 ); at $40 / 30{ }^{\circ} \mathrm{C}$ $(12 / 12 \mathrm{~h}), 98 \%$ of the shoots were longer than $10 \mathrm{~mm}$ (data not shown).

Thermoperiodicity was further tested by examining the extent of elongation caused by alternating and constant temperatures greater than the optimum temperature (Table 1). At mean temperatures exceeding the optimal constant temperature $\left(35^{\circ} \mathrm{C}\right)$, alternating temperature regimes generally caused more elongation than at the corresponding mean constant temperatures, including one

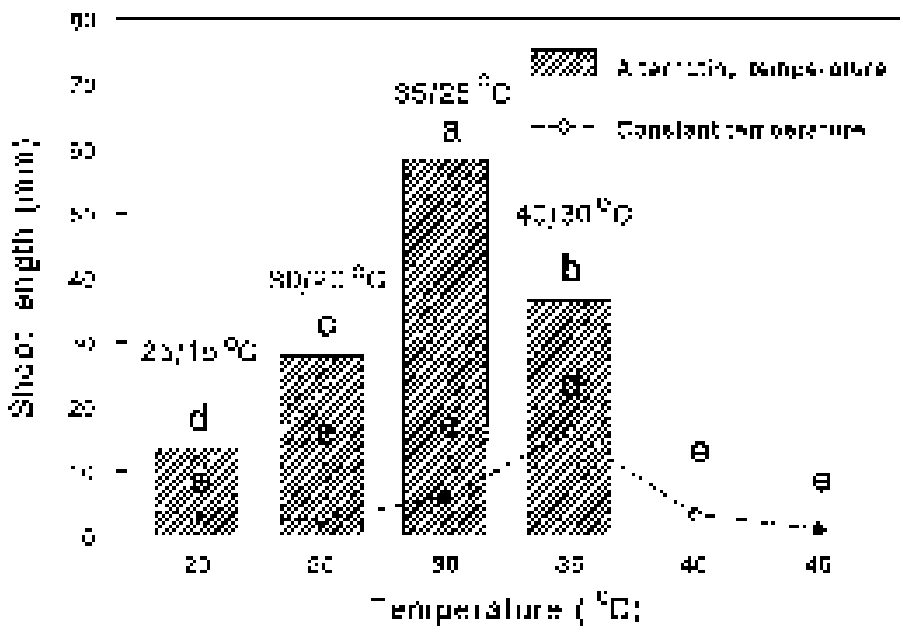

Fig. 1. Response of purple nutsedge shoot elongation to constant and alternating temperature regimes. The response of shoot elongation to constant temperatures is depicted by the line graph, and the alternating temperature regimes by the bar graph. Data points within alternating temperatures or within constant temperatures with different letters differ significantly by Duncan's multiple range test, $P=0.05$. 
Table 1. Response of purple nutsedge shoot elongation to supraoptimal constant temperatures and alternating temperature regimes.

\begin{tabular}{lc}
\hline \hline $\begin{array}{l}\text { Temp regime } \\
\left({ }^{\circ} \mathrm{C}\right)\end{array}$ & $\begin{array}{c}\text { Shoot length } \\
(\mathrm{mm})\end{array}$ \\
\hline 38 & $9.1 \mathrm{c}^{\mathrm{z}}$ \\
$41 / 35(12 / 12 \mathrm{~h})$ & $27.7 \mathrm{a}$ \\
40 & $9.3 \mathrm{c}$ \\
$45 / 35(12 / 12 \mathrm{~h})$ & $16.1 \mathrm{~b}$ \\
$42 / 38(12 / 12 \mathrm{~h})$ & $15.3 \mathrm{~b}$ \\
42 & $3.1 \mathrm{c}$ \\
$45 / 39(12 / 12 \mathrm{~h})$ & $5.5 \mathrm{c}$ \\
\hline
\end{tabular}

$\overline{{ }^{\mathrm{z}} \text { Means followed by different letters differ significantly by Duncan's }}$ multiple range test, $P=0.05$.

regime with only a $4{ }^{\circ} \mathrm{C}$ daily temperature difference. The only exception was for the highest alternating temperature regime tested $\left(45 / 39^{\circ} \mathrm{C}\right)$, where elongation was not different than in the 42 ${ }^{\circ} \mathrm{C}$ constant temperature regime (Table 1$)$.

MAgnitude OF DAILY ALTERNATING TEMPERATURES. Shoot length at alternating temperatures with daily temperature differences of 8 or $12{ }^{\circ} \mathrm{C}$ increased to $>8$-fold compared to the constant mean temperature of $24^{\circ} \mathrm{C}$, and $88 \%$ and $98 \%$ of the shoots were longer than $10 \mathrm{~mm}$, respectively (Fig. 2). Exposure to daily temperature differences of 2 or $4{ }^{\circ} \mathrm{C}$ around a $24{ }^{\circ} \mathrm{C}$ mean temperature did not significantly promote shoot extension within $7 \mathrm{~d}$, and only $28 \%$ of the shoots subjected to a difference of $4{ }^{\circ} \mathrm{C}$ were longer than 10 $\mathrm{mm}$.

Number Of FluCtuAting TEMPERATURE CyCles. Shoot elongation increased in a sigmoidal fashion with increasing alternating temperature cycles (Fig. 3). A sigmoidal curve accounted for $97 \%$ of the variation in shoot elongation.

Duration OF UPPER AND LOWER TEMPERATURE PHASES. The effective duration of the high and low temperature periods varied with different temperature regimes. Maximal shoot length occurred with upward shifts from 30 to $40{ }^{\circ} \mathrm{C}$ for 1 to $3 \mathrm{~h}$ and shoot length declined as the daily duration of the $40{ }^{\circ} \mathrm{C}$ upper temperature exceeded $3 \mathrm{~h}$ (Fig. 4). In the $30 / 20{ }^{\circ} \mathrm{C}$ fluctuating temperature regime, shoot length was $<50 \%$ of maximum with a 1 to $3 \mathrm{~h}$ upward shift from 20 to $30^{\circ} \mathrm{C}$ and was maximum at $\approx 15 \mathrm{~h}$ at $30{ }^{\circ} \mathrm{C}$ (Fig. 4 ). Shoot length declined as the duration of the upper temperature (30 ${ }^{\circ} \mathrm{C}$ ) increased from 15 to $24 \mathrm{~h}$.

\section{Discussion}

Greater elongation at alternating daily temperatures than at the mean constant suboptimal, optimal, and supraoptimal temperatures over a wide range of constant temperatures (Fig. 1, Table 1) shows that the purple nutsedge shoot elongation response was thermoperiodic. The shoot elongation response met the established criteria for thermoperiodicity, which is the demonstration of greater growth at alternating temperature than at the optimal constant mean temperature (Dale, 1964; Friend and Helson, 1976).

Diurnally alternating temperatures caused more shoot elongation than constant temperatures with the same mean temperature on a wide range of species. These species included Easter lily (Lilium longiflorum Thunb.) (Erwin et al., 1989), chrysanthemum (Chrysanthemum morifolium Ramat.) (Karlsson and Heins, 1986), bellflower (Campanula isophylla Mor.) (Moe, 1990), cucumber (Grimstad and Frimanslund, 1993), soybean (Warrington et al., 1977), and tomato (Heuvelink, 1989). Those studies did not test for thermoperiodicity at optimal constant temperatures as suggested by Dale (1964), although the stimulation of shoot elongation by diurnally alternating temperature appeared to be a relatively common phenomenon.

Few studies have pursued an understanding of the alternating temperature stimulation of shoot elongation. The stimulation of shoot elongation by alternating temperature only occurred when the high temperature was associated with the day period; if the low temperature was associated with the day period, shoot elongation was equivalent or lower than at constant temperature (Erwin et al., 1989; Grimstad and Frimanslund, 1993; Jensen et al., 1996; Moe, 1990). Erwin et al. (1989) stated that their unpublished studies showed that the effect of temperature on Easter lily shoot elongation was not affected by increasing or decreasing the irradiance under which plants were grown between 50 and $400 \mu \mathrm{mol} \cdot \mathrm{m}^{-2} \cdot \mathrm{s}^{-1}$. Moe (1990) also reported that the thermomorphogenic effect on shoot elongation of bellflower was not greatly influenced by changes in irradiance levels. Thus, both Erwin et al. (1989) and

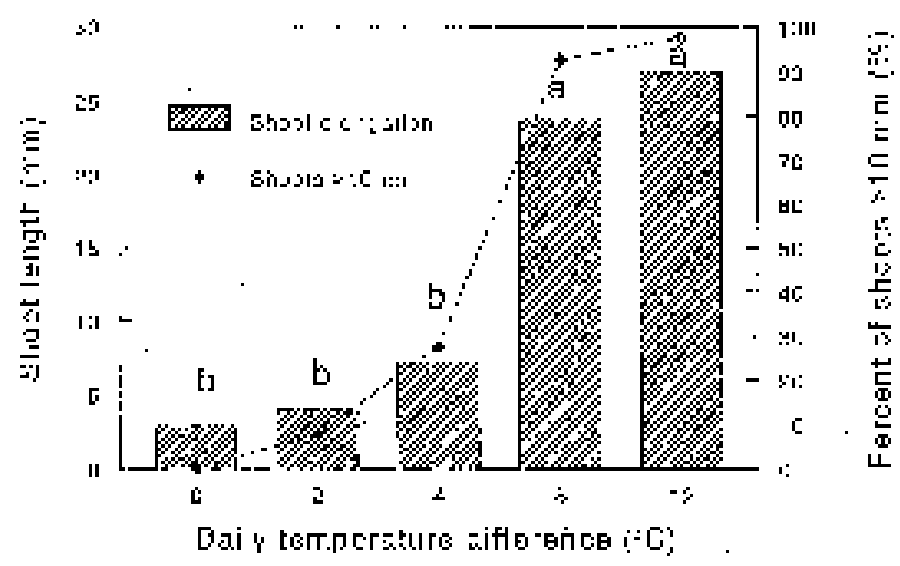

Fig. 2. Response of purple nutsedge shoot elongation to the daily temperature difference of the alternating temperature cycle. Each alternating temperature regime has $12 \mathrm{~h}$ high and $12 \mathrm{~h}$ low temperature around a mean temperature of 24 ${ }^{\circ} \mathrm{C}$. Bars within a response variable (length or percent) with different letters differ significantly by Duncan's multiple range test, $P=0.05$. The mean separation of shoot length and the number of shoots larger than $10 \mathrm{~mm}$ are identical, so the bar and line graphs share the same letters.

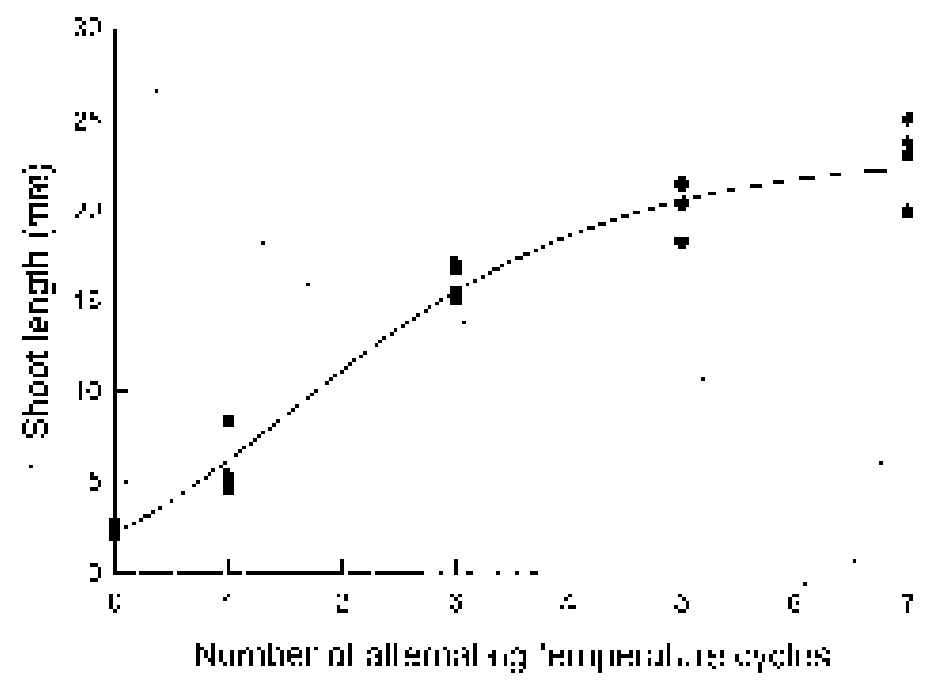

Fig. 3. Response of purple nutsedge shoot elongation to the number of alternating cycles. One high temperature pulse $\left(40{ }^{\circ} \mathrm{C}\right.$ for $\left.1 \mathrm{~h}\right)$ was inserted after $23 \mathrm{~h}$ incubation at $20^{\circ} \mathrm{C}$ in each alternating cycle. Tuber sprouts were incubated at 20 ${ }^{\circ} \mathrm{C}$ after exposure to the indicated number of alternating cycle(s). The fitted model is $\mathrm{Y}=-0.5913+23.8404 /(1+\exp (-(\mathrm{x}+1.4233) / 1.6189))^{6.2}$. Observations with the same value are hidden from view. 


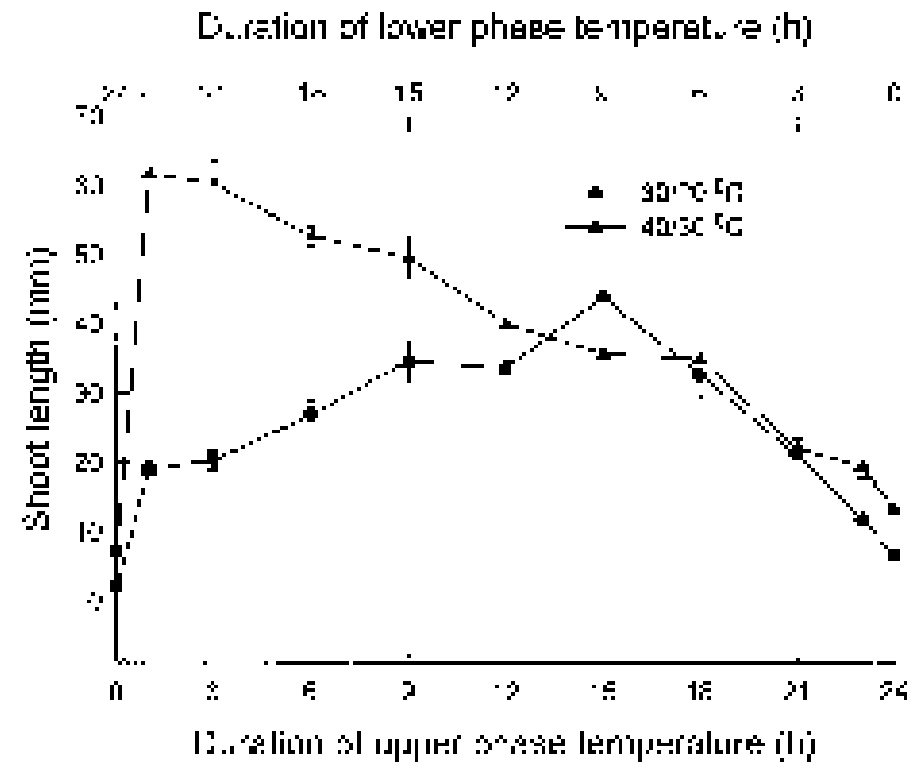

Fig. 4. Response of purple nutsedge shoot elongation to the duration of upper and lower temperature phases of the alternating temperature regimes (30/20 and 40/ $30{ }^{\circ} \mathrm{C}$ ). After seven cycles, the shoot length was determined. The values for shoot elongation at constant lower and higher temperatures are at 0 and $24 \mathrm{~h}$ respectively. Horizontal bars represent $\pm \mathrm{SE}$.

Moe (1990) suggested that thermomorphogenesis was probably not related to irradiance levels and carbohydrate supply, and that it may be mediated by differences in gibberellin $(2,4 \alpha, 7$-trihydroxy-1-methyl-8-methylenegibb-3-ene-1,10-dicarboxylic acid $1,4 \alpha$-lactone). Erwin et al (1989) showed that a gibberellin biosynthesis inhibitor, ancymidol ( $\alpha$-cyclopropyl- $\alpha$-(4-methoxyphenyl)5-pyrimidinemethanol) reduced shoot elongation and its effect was decreased as the difference between day and night temperature decreased. Similar results were obtained with daminozide ((butanedioic acid mono(2,2-dimethylhydrazide) on bellflower, while applications of $\mathrm{GA}_{3}$ overcame the stem elongation inhibition (Moe, 1990). In addition, Jensen et al. (1996) showed that diurnally alternating temperatures that stimulated shoot elongation in bellflower were accompanied by an increase in $\mathrm{GA}_{1}, \mathrm{GA}_{19}$, and $\mathrm{GA}_{44}$.

The strong control of purple nutsedge shoot elongation by varying the duration of the high and low temperature periods with different temperature regimes has important practical implications. Alternating temperature cycles of only $1 \mathrm{~h}$ at $40{ }^{\circ} \mathrm{C}$ and $23 \mathrm{~h}$ at $30{ }^{\circ} \mathrm{C}$ treatment were sufficient to obtain a maximal level of shoot elongation, while shoot elongation declined as the duration at lower phase temperature decreased over the range from 18 to 0 $\mathrm{h}$ (Fig. 4). A similar pattern of shoot elongation was observed at the lower alternating temperature regime of $30 / 20{ }^{\circ} \mathrm{C}$ (Fig. 4). Thus, models to predict emergence of purple nutsedge should consider the daily fluctuation in temperature.

An increased understanding of temperature regulation of the sprouting process may be valuable for the imposition of management strategies. Purple nutsedge budbreak and shoot elongation are thermally regulated and require a daily temperature differential (Nishimoto et al., 1995). For budbreak, only the upward shift in a fluctuating temperature regime was effective; a single shortduration high temperature pulse was sufficient to terminate dormancy (Sun and Nishimoto, 1997). In contrast, shoot elongation was stimulated by both upward and downward shifts (Fig. 1, Table 1). Multiple daily alternating temperature cycles were required for maximal elongation, and increasing numbers of high temperature pulses stimulated shoot elongation in a sigmoidal pattern (Fig. 3).
Increasing the daily temperature difference increased tuber sprouting (shoots exceeded $10 \mathrm{~mm}$ ) and shoot extension (Fig. 2). This agrees with the finding of Miles et al. (1996). Shoot extension was also greater when the daily temperature difference was $4{ }^{\circ} \mathrm{C}$ around a mean of $40{ }^{\circ} \mathrm{C}$ (Table 1) rather than $24{ }^{\circ} \mathrm{C}$ (Fig. 2). However, little shoot elongation occurred when the mean of the alternating temperature increased to $42{ }^{\circ} \mathrm{C}$ or at constant $42{ }^{\circ} \mathrm{C}$ (Table 1) and $45{ }^{\circ} \mathrm{C}$ (Fig. 1). This is consistent with previous studies, where no tuber sprouting occurred if tubers were exposed to constant temperatures of 43 to $45^{\circ} \mathrm{C}$ (Holt and Orcutt, 1996; Miles, 1991; Ueki, 1969).

Both the mean temperature and the daily temperature difference are important factors in the application of soil solarization to increase sprouting of purple nutsedge (Miles, 1991). The mean daily soil temperature at $15 \mathrm{~cm}$ depth ranged from 22 to $27^{\circ} \mathrm{C}$ at a low elevation site in Hawaii and the daily difference between minimum and maximum was $\angle 2{ }^{\circ} \mathrm{C} ; \approx 70 \%$ of the tubers sprouted within 3 to 5 weeks under these conditions (Miles, 1991). Under soil solarization, the mean daily soil temperature at $15 \mathrm{~cm}$ depth increased to 28 to $32^{\circ} \mathrm{C}$ and the daily difference between minimum and maximum was $\approx 4$ to $5{ }^{\circ} \mathrm{C}$; under these conditions $\approx 97 \%$ of the tubers sprouted (Miles, 1991). Thus, soil solarization may be useful to stimulate and synchronize purple nutsedge emergence, which could be followed by application of an effective herbicide.

The requirement for multiple cycles of alternating temperature to cause elongation of purple nutsedge may be important to its survival. Budbreak occurs readily for most tubers without any alternating temperature stimulation, and dormant tubers may be readily released from dormancy by a brief high temperature pulse (Sun and Nishimoto, 1997). If the temperature remains relatively constant, most purple nutsedge buds will not elongate. The sprouts will emerge when the temperature is high enough with adequate temperature difference between day and night. Favorable alternating temperature conditions occur when a plant canopy above the soil surface is removed (Rubin and Benjamin, 1984). Under such conditions, purple nutsedge can grow without competition with other plants. This sensing mechanism would assess whether environmental conditions were favorable or adverse for purple nutsedge and thereby regulate its emergence.

\section{Literature Cited}

Benech Arnold, R.L., C.M. Ghersa, R.A. Sanchez, and A.E. Garcia Fernandez. 1988. The role of fluctuating temperatures in the germination and establishment of Sorghum halepense (L.) Pers. Regulation of germination under leaf canopies. Functional Ecol. 2:311-318.

Dale, J.E. 1964. Some effects of alternating temperature on the growth of French bean plants. Ann. Bot. 28:127-135.

Erwin, J.E., R.D. Heins, and M.G. Karlsson. 1989. Thermomorphogenesis in Lilium longiflorum. Amer. J. Bot. 76:47-52.

Friend, D.J.C. and V.A. Helson. 1976. Thermoperiodic effects on the growth and photosynthesis of wheat and other crop plants. Bot. Gaz. 137:75-84.

Glasziou, K.T., T.A. Bull, M.D. Hatch, and P.C. Whiteman. 1965. Physiology of sugar cane. VII. Effects of temperature, photoperiod duration, and diurnal and seasonal temperature changes on growth and ripening. Austral. J. Biol. Sci. 18:53-66.

Grimstad, S.O. and E. Frimanslund. 1993. Effect of different day and night temperature regimes on greenhouse cucumber young plant production flower bud formation and early yield. Scientia Hort. 53:191-204.

Haroon, M., R.C. Long, and J.A. Weybrew. 1972. Effect of day/night temperature on factors associated with growth of Nicotiana tabacum $\mathrm{L}$. in controlled environments. Agron. J. 64:509-515.

Harrington, G.T. 1923. Use of alternating temperatures in the germination of seeds. J. Agr. Res. 23:295-232.

Holt, J.S. and D.R. Orcutt. 1996. Temperature thresholds for bud sprout- 
ing in perennial weeds and seed germination in cotton. Weed Sci. 44:523-533.

Heuvelink, E. 1989. Influence of day and night temperature on the growth of young tomato plants. Scientia Hort. 38:11-12.

Jensen, E., S. Eilertsen, A. Ernsten, O. Juntilla, and R. Moe. 1996. Thermoperiodic control of stem elongation and endogenous gibberellins in Campanula isophylla. J. Plant Growth Regul. 15:167-171.

Karlsson, M.G. and R.D. Heins. 1986. Response surface analysis of flowering in Chrysanthemum 'Bright Golden Anne'. J. Amer. Soc. Hort. Sci. 111:253-259.

Lionakis, S.M. and W.W. Schwabe. 1984. Some effects of daylength, temperature and exogenous growth regulator application on the growth of Actinidia chinensis Planch. Ann. Bot. 54:485-501.

Miles, J.E. 1991. Modeling the sprouting of Cyperus rotundus L. tubers in response to soil temperatures under soil solarization. $\mathrm{PhD}$ diss. Univ. of Hawaii, Honolulu.

Miles, J.E., R.K. Nishimoto, and O. Kawabata. 1996. Diurnally alternating temperatures stimulate sprouting of purple nutsedge (Cyperus rotundus) tubers. Weed Sci. 44:122-125.

Moe, R. 1990. Effect of day and night temperature alternations and of plant growth regulators on stem elongation and flowering of the longday plant Campanula isophylla Moretti. Scientia Hort. 43:291-305.

Morinaga, T.I. 1926. Effect of alternating temperatures upon the germination of seeds. Amer. J. Bot. 13:141-158.

Nishimoto, R.K. and L.B. McCarty. 1997. Fluctuating temperature and light influence seed germination of goosegrass (Eleusine indica). Weed Sci. 45:426-429.

Nishimoto, R.K., J.E. Miles, and W.H. Sun. 1995. Thermal control of purple nutsedge (Cyperus rotundus) bud break and shoot elongation. Proc. Asian-Pacific Weed Sci. Soc. Conf. 15:484-487.
Rajan, A.K. and G.E. Blackman. 1975. Interacting effects of light and day and night temperatures on the growth of four species in the vegetative phase. Ann. Bot. 39:733-743.

Rubin, B. and A. Benjamin. 1984. Solar heating of the soil: involvement of environmental factors in the weed control process. Weed Sci. 32:138142.

Sun, W.H. and R.K. Nishimoto. 1997. Dormancy release of purple nutsedge tuber buds by a single thermal pulse. J. Amer. Soc. Hort. Sci. 122:306-309.

Thompson, K., J.P. Grime, and G. Mason. 1977. Seed germination in response to diurnal fluctuation of temperature. Nature 267:147-149.

Totterdell, S. and E.H. Roberts. 1980. Characteristics of alternating temperature which stimulate loss of dormancy in seeds of Rumex obtusifolius L. and Rumex crispus L. Plant Cell Environ. 3:3-12.

Tripathi, R.S. 1967. Ecology of Cyperus rotundus L. II. Tuber sprouting in relation to temperature. Proc. Nat. Acad. Sci. India (B) 37:409-412.

Ueki, K. 1969. Studies on the control of nutsedge (Cyperus rotundus L.): On the germination of a tuber. Proc. 2nd Asian-Pacific Weed Sci. Soc. Conf. 2:355-369.

Ulrich, A. 1952. The influence of temperature and light factors on the growth and development of sugar beets in controlled climatic environments. Agron. J. 44:66-73.

Warrington, I.J., M. Peet, D.T. Patterson, J. Bunce, R.M. Haslemore, and H. Hellmers. 1977. Growth and physiological responses of soybean under various thermoperiods. Austral. J. Plant Physiol. 4:371-380.

Wellensiek, S.J. 1957. The plant and its environment, p. 3-15. In: J.P. Hudson (ed.). Control of the plant environment. Butterworths, London. Went, F.W. 1944. Plant growth under controlled conditions. II. Thermoperiodicity in growth and fruiting of the tomato. Amer. J. Bot. 31:135150. 